\title{
Kistik Fibrozis ve Benzer Solunum Yolu Hastalıklarında Silya Yapı ve İşlev Bozuklukları
}

\section{Cilia Structure and Function Defects in Cystic Fibrosis and Related Respiratory Diseases}

\author{
Merve ATALAY, Didem DAYANGAÇ ERDEN
}

Hacettepe Üniversitesi Tıp Fakültesi, Tıbbi Biyoloji Anabilim Dalı, Ankara, Türkiye

\begin{abstract}
öz
Hücre yüzeyinde bulunan silyalar kistik fibrozis, primer siliyer diskinezi ve kronik obstrüktif akciğer hastallklarında yapı ve ișlev bozukluğuna uğrayarak hastalık patogenezinde önemli rol oynarlar. Silya oluşumu sırasında özellikle hareketli silya yapısını oluşturan genlerde görülen mutasyonlar sonucu silyanın mikrotübül yapısı bozulur ve silya yüzeyinde çıkıntılar ile büzülmeler meydana gelir yada silya yapısı olușamaz. Silyada olușan bu deformasyonlar sonucunda silya ișlevinin kaybı gerçekleșmekte ve siliyer atım frekansında azalma görülmektedir. Bu azalıș, mukusun havayollarındaki yabancı mikroorganizmalardan ve bakterilerden temizlenme mekanizması olarak adlandırlan mukosiliyer klirens mekanizmasını bozmaktadır. Mukusun epitel yüzeyden temizlenememesi, fazla üretilmesi ve kalınlaşması sebebiyle ortama göç eden makrofajlar ve nötrofiller sitokin firtınasına neden olmakta, inflamatuar yolakların aktifleșmesiyle hastalık seyri ağıllaşmaktadır. Bu derlemede kistik fibrozis, primer siliyer diskinezi ve kronik obstrüktif akciğer hastalıklarında hareketli silya oluşumunda görev alan ve doğrudan ya da dolaylı olarak ifade değişimi gösteren genler ve ișlevleri özetlenmiştir. Ilișkili genlerin ifade değişimleri sonucunda akciğer epitel yüzeyindeki hücreler farkllaşarak akciğer hastalığı patofizyolojisi etkilenmektedir.
\end{abstract}

Anahtar Sözcükler: Gen ifade profili, Mukosiliyer klirens, Silya, Solunum bozuklukları

\begin{abstract}
The cilia found on the cell surface contribute to disease pathogenesis in cystic fibrosis, primary ciliary dyskinesia, and chronic obstructive pulmonary diseases by showing defects in structure and function. As a result of mutations in the genes responsible from mobile cilia structure, the microtubule structure is disrupted and protrusions and shrinkage occur in the cilium. These deformations cause loss of cilia function and decrease in ciliary beat frequency. This decrease disrupts the mucociliary clearance mechanism, which is called as the clearance mechanism of mucus from foreign microorganisms and bacteria in the airways. The macrophages and neutrophils migrating to the environment cause cytokine storm due to the inability of mucus to be cleared from the epithelial surface and the disease course exacerbates with the activation of inflammatory pathways. In this review, genes that have a function in mobile cilia formation and that show direct or indirect expression changes in cystic fibrosis, primary ciliary dyskinesia, and chronic obstructive pulmonary diseases are summarized. As a result of change in the expression of these genes, cell differentiation on the lung epithelial surface and pathophysiology of lung diseases are affected.
\end{abstract}

Key Words: Gene expression profile, Mucociliary clearance, Cilia, Respiration disorders

(1)
Çıkar Çatışması / Conflict of Interest: : Tüm yazarlar adına, ilgili yazar çıkar çatıșması olmadığını belirtir.

0000-0001-6965-422X Atıf yazım şekli / How to cite : Atalay M, Dayangaç Erden D,. Kistik Fibrozis ve Benzer Solunum Yolu Hastalıklarında Silya yapı ve Ișlev Bozuklukları. 0000-0002-0236-7565 Türkiye Çocuk Hast Derg 2021;15:545-552. 


\section{GiRiş}

Günümüzde 'tüy benzeri hücresel organel' olarak tanımlanan silyalar, ilk olarak mikroskobun keşfiyle birlikte 'küçük hareketli ayaklar' olarak Antony Van Leeuwenhoek tarafindan araştııımıştır (1). Daha sonra yapılan çalışmalarla silyaların hareketsiz yapıda da bulunabileceği keșfedilmiș ve transmisyon elektron mikroskobu ile silya yapısı detaylandırılmıştır (2).

Silya oluşumu silyogenez olarak adlandırılmaktadır (3). Sentriyol çiftlerinden biri hücre zarına yerleşerek bazal cisim adı verilen yapıyı oluşturmaktadır. Diğer sentriyol çifti perisentriyoler matriks denilen hücre zarının alt kısmındaki yüzeyde yerleşim göstermektedir (4). Bu silindirik yapının hücre zarından dışa doğru uzamasıyla aksonem oluşmaktadır. Aksonem yapısına göre silyalar; hareketli (nodal ve motor) ve hareketsiz olarak sınıflandırımaktadır. Nodal silyaların yapısı 9 çift "a ve b" mikrotübülü içerirken $(9+0)$, motor silyalar 9 çift mikrotübüle ek olarak 2 tane merkezi mikrotübül yapısı (9+2) içermektedir (Şekil 1) (5). Hareketli silyalar; beyindeki beyin omurilik sıvısının, solunum sistemindeki mukusun, spermin hareketlerinden ve solunan parçacıkların dışarı atımasından sorumludur. Ayrıca embriyo gelişiminde sağ ve sol gövde ekseninin oluşması ile organ yerleşimini düzenlemektedirler. Hareketsiz silyalar $(9+0)$ ise katı bir yapıya sahiptir, kanal ve tübüler yapı içindeki sıvı akıșını tespit etmekle sorumludur. Özellikle duyu sistemi hücrelerinde görev almaktadırlar. Örneğin retinadaki çubuk ve koni hücrelerinde yer alan silyalarda bazı özelleşmiş reseptörler bulunması sebebiyle bu silyalar ışığı tespit etmektedirler (6).

Hareketli silyaların yapısında yer alan 13 alt birimden oluşan "a" ve 11 alt birimden oluşan "b" mikrotübülleri, neksin-dynein regülatör kompleks (NDRC) adı verilen yapı ile birbirine bağlanmaktadır
(7). Neksin, silya yapısındaki iç ve dış dynein kollarını kontrol etmektedir. İç dynein kolu ve dış dynein kolu yapılarının içinde dynein ağır zincirleri bulunur ve bu zincirlerin ATP ile aktifleşmesi ile mikrotübüllerin birbiri üzerinden kayması ve silyanın hareketi sağlanmaktadır (Șekil 1). Bu kayma hareketinin frekansı, siliyer atım frekansı olarak adlandırımaktadır. Mukus ve perisiliyer tabaka arasında mukusun ve silyanın hızı arasındaki bağlantı ile hesaplanan bu değer, sağlıklı hücrelerde 12-15 hz arasında ölçülmektedir (8). Ayrıca silyalar mukus ile sadece mukusun epitel yüzeyden atıldığı yönde yani ileri yönde temas etmektedir ve bu mekanizma mukusun geri yönde akışını önlemektedir. Dış dynein kolu yapısı silya hareketinde siliyer atım frekansını düzenlerken, iç dynein kolu ise bükülmeyi ve dalga-benzeri hareketi sağlamaktadır (9).

Siliyer matriks silya yapısına direkt temas etmemekte olup; aradaki boșluk silyaların mikrotübül yapısı ve siliyer membran arasında çift yönlü bir taşıma sağlayan intraflagellar transport (IFT) alanını olușturmaktadır. Silyanın olușumu ve ișlevi için gerekli yapı taşları olan tübülin dimerleri bu şekilde taşınmaktadır. Ayrıca bu proteinlerin silyaya giriş-çıkışı ve seçiciliği transisyon bölgesi ve $Y$ bağlantıları ile sağlanmaktadır. Taşıma bazal membrandan silyanın ucuna doğru kinesin proteini ile gerçekleşmekte ve ileri yönde taşınım (anterograd) olarak adlandırımaktadır (10). Silya ucundan bazal membrana doğru olan taşıma geri yönde (retrograd) olarak adlandırımakta ve dynein proteini yardımcı eleman olarak kullanılmaktadır. Bu iki yönlü taşımalar sonucunda sabit bir siliyer uzunluğa yol açan dinamik bir dengeye ulaşılmaktadır. Taşıma işlemi gerçekleşirken taşıma yönüne bağlı olarak IFT A ve B adı verilen yardımcı molekül grubu kullanımaktadır (11). Dynein ile birlikte retrograd tașımada yer alan IFTA geninde meydana gelen bir mutasyon sonucu silya ucundaki birikimlerden kaynaklı çıkıntılar

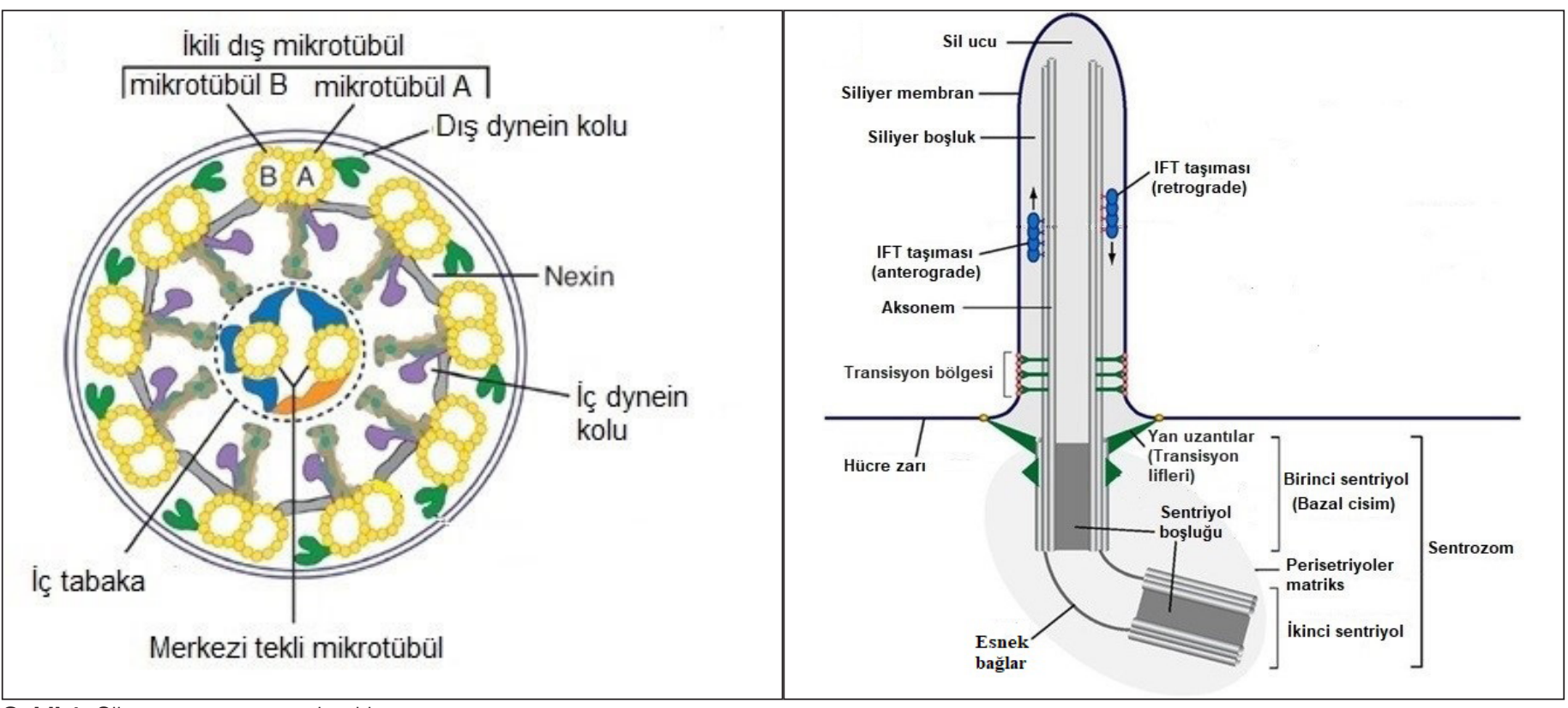

Şekil 1: Silya yapısının yatay kesiti

Şekil 2: Silya yapısının dikey kesiti 
gözlenmektedir. Kinesin ile birlikte anterograd taşımada yer alan IFTB geninde saptanan mutasyon sonucunda ise silyanın ucuna doğru taşıma gerçekleşememekte ve silyada toplanma ile büzülmeler gözlemlenmektedir (Şekil 2) (12).

\section{Alt Solunum Yolu Hücreleri ve Silyalı Hücre Farklılașması}

Trakeadaki kıkırdaklı hava yolu, çeşitli seröz, salgı, goblet, kulüp ve siliyer hücre içeren çok sayıda submukozal bez içerir. Bu hücreler bazal, orta ya da farklılaşmamış, silyalı ve salgı hücreleri olarak 4 gruba ayrılmaktadır (13). Yüzey epitel hücre katmanının altında yer alan bazal hücreler, hava yolları boyunca yer alıp; farkllaşma ve onarım sırasında belirli transkripsiyon faktörleri yardımıyla silyalı, salgı ve goblet hücrelerinin oluştuğu progenitör hücreler olarak görev yaparlar (14).

Bu farkllaşma temel olarak Notch sinyali varlığı ve seviyesine göre belirlenmektedir. Notch sinyali varlığında salgı hücrelerinden olan kulüp ve seröz hücreleri oluşmaktadır. Bu hücreler alt solunum yollarındaki küçük salgı bezlerini oluşturmaktadırlar. Kulüp hücreleri SPDEF transkripsiyon faktörü (SAM Pointed Domain Containing ETS Transcription Factor) varlığında mukusun yapısını oluşturan müsin proteinlerini salgılayan goblet hücrelerini oluşturmaktadır (15). Bu yüzden submukozal bezlerde aynı zamanda müsin oluşumu ve paketlenmesi sağlanmaktadır. Normal şartlarda 3-4 ayda yenilenen silyalı hücre yapısı, hasar olduğunda kulüp hücreleri yardımı ile 14 günde yenilenmektedir (16). Notch sinyalinin olmadığı durumda ise Geminin-colied coil containing (GMNC) proteinlerinin ve multiciliate differentiation and DNA synthesis associated cell cycle protein (MCIDAS), Myeloblastosis proto-oncogene (MYB), regulatory factor $X$ $(R F X)$ genlerinin aktifleșmesiyle sentriyol biyogenezi, çok silyalı hücre oluşumu, tek silyalı hücre oluşumu ve özellikle Forkhead Box J1 (FOXJ1) geninin ifadesi etkilenmektedir (15).

\section{Mukosiliyer Klirens Mekanizması}

Mukosiliyer klirens, mukusun taşınması yoluyla havayolunun yabancl mikroorganizmalardan ve bakterilerden temizlenme mekanizması olarak tanımlanmaktadır (17). Hava yolu yüzey tabakası 2-5 mm kalınlığındaki mukustan ve 7 mm kalınlığındaki perisiliyer tabakadan oluşmaktadır. Hücre zarında görülen aktif iyon geçişleri ile optimal bir silya performansı ve mukusun hidrasyonu sağlanmaktadır (18). Bu aktif iyon geçişleri arasında yer alan $\mathrm{Na}+$ alımı ENaC reseptörleri, $\mathrm{Cl}$ - salınımı cystic fibrosis transmembrane regulator (CFTR) ve CaCC kanalları aracilı̆ı̆ıla gerçekleştirilmektedir. Ayrıca Na, K ve Na-K-2Cl ortak taşıyıcıları ile birlikte elektrokimyasal bir fark oluşturulmaktadır. Mukus tabakası salgı hücrelerinden salınan müsin proteinlerinin karışımı ile oluşmaktadır (19). Mukusun jel tabakasını mucin 5B (MUC5B) ve mucin 5AC (MUC5AC) proteinleri oluşturmaktadır (20). Mucin 1 (MUC1) ve mucin 2 (MUC2) ile ilișkili kesin veriler bulunmasa da bazı hipotezler mevcuttur. MUC1'in bakteri enfeksiyonlarının baskılamasında rol oynaması nedeniyle Toll-like reseptörler (TLR) ile bağlantıı olabileceği ve MUC2'nin de aslında sindirim sistemi mukusunda olmasına rağmen kistik fibrozis (KF) ve kronik obstrüktif akciğer hastalıklarında (KOAH) ifadesi azaldığı için etkisinin olabileceği düşünülmektedir (21).

Ortamda Notch sinyalinin fazla olduğu durumlarda bazal hücreler direkt goblet hücrelerine dönüșmektedir. Bu durum MUC5B ve MUC5AC müsinlerinin fazla miktarda üretilmesine, mukusun kalınlașmasına ve tıkanıkığa sebep olmaktadır. Fazla miktarda üretimin sonucu olarak mukusun jel yapısı bozulmaktadır. Tıkanıklık sebebiyle ortama göç eden makrofajlar ve nötrofiller sitokin firtınasına neden olmaktadır (13). Ortamda bakteri enfeksiyonunun olduğu durumlarda ise baskın bir hümoral yanıt, enfeksiyona karșı spesifik $T$ yardımcı hücreleri yanııındaki farkllıklardan dolayı ise zayıf bir hücresel yanıt görülmektedir (22). Enfeksiyonun bitmemesi sebebiyle inflamasyon sürekli devam etmekte ve kronik akciğer hastalıkları görülmektedir.

\section{Kronik Hava Yolu Hastalıklarında Hareketli Silya Yapı ve İşlev Bozuklukları}

Bronşların aşırı genişlemesi anlamına gelen bronşektazi, kronik hava yolu sürpüratif hastalıklarının tamamında ortak olarak gözlenmektedir (23). Silyalar normal șartlarda biriken mukusu ve partikülleri akciğerden uzaklaştırmaktadırlar. Fakat bronşektazi durumunda silyaların yok olması veya sayısının azalması sebebiyle, süpürme işlemi gerçekleştirilememektedir. Mukusun birikmesi, mukosiliyer klirensin bozulması, bakteri yerleşimi ve inflamasyon bir döngü şeklinde tekrarlanmaktadır. Bu döngü bronş duvarı yıkımına ve genişlemesine yol açan olaylar zincirini ortaya çıkardığı için 'Cole tehlikeli kısır döngüsü' olarak adlandırılan hipotez ile desteklenmektedir (24).

Üst ve alt solunum yolu hastalikları, alerjik ve alerjik olmayan hastalık grupları ayrı ayrı kümelendiğinde ortak olarak hareketli silya bozuklukları görülmektedir. Alt solunum yolu hastalıklarından olan primer siliyer diskinezi, kronik obstrüktif akciğer hastalığı ve kistik fibrozis alerjik olmayan hastallılar grubuna girmektedir. Bozuklukların etkisi olarak silyogenezde azalma, siliyer yapıdaki anormallikler ve bozulmuş siliyer hareket gözlemlenmektedir (25). Zayıf yapıda silya oluşumuna FOXJ1, centriolar coiled-coil protein 110 (Cp110) ve tumor protein p73 (Tap73) genlerindeki mutasyonlar neden olmaktadır (26). Aynı zamanda MCIDAS, dynein axonemal heavy chain 5 (DNAH5) ve coiled-coil domain containing 39 (CCDC39) gibi aksonemal motor proteinler, CyclinO ve FOXJ1 tarafindan kontrol edilmekte olup; CyclinO ve FOXJ1 genlerindeki mutasyonlar silya olușumunda hatalara neden olmaktadır (27). Tablo I'de kistik fibrozis, primer siliyer diskinezi ve kronik obstrüktif akciğer hastalıklarında mukosiliyer klirens ve silya yapı ve işlevinden sorumlu olan genler özetlenmiştir.

\section{Kistik Fibrozis}

Kistik fibrozis, cystic fibrosis transmembrane regulator (CFTR) genindeki mutasyonlar sonucu otozomal resesif olarak kalıtlan genetik bir hastalıktır. CFTR geni kromozomun 7q31.2 
Tablo 1: Kistik fibrozis, primer siliyer diskinezi ve kronik obstrüktif akciğer hastalıklarında mukosiliyer klirens ve silya yapı ve işlevinden sorumlu olan genler özetlenmiștir.

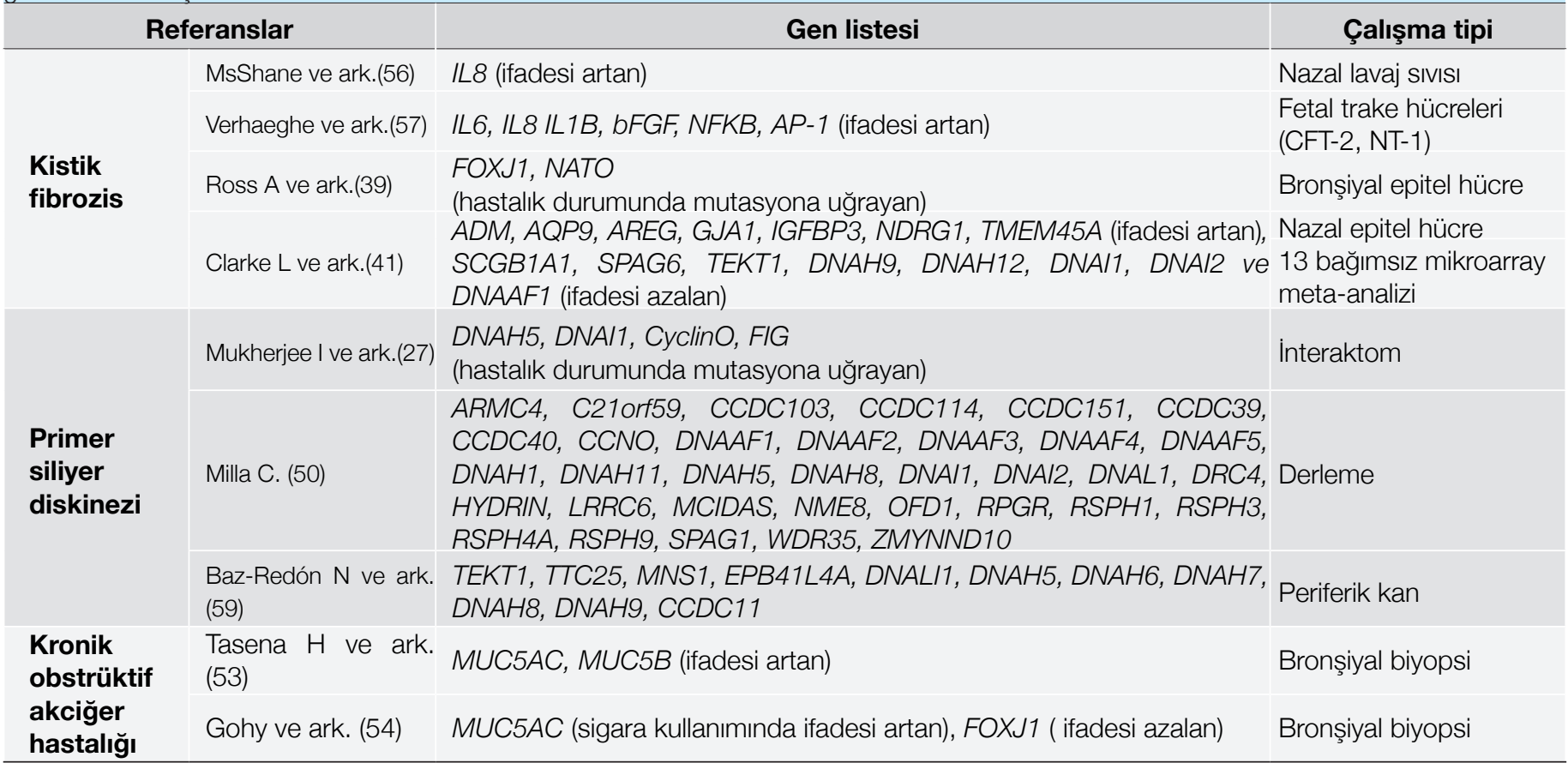

bölgesinde haritalanmıştır (28). Günümüzde CFTR geninde 2000'den fazla mutasyon tanımlanmış olup; mutasyonlar etnik kökene bağlı olarak değişiklik göstermektedir (29,30). Genetik olarak heterojen bir toplum olan Türk toplumunda görülen mutasyonlar da Avrupa toplumlarından farklıdır (30). CFTR proteini endoplazmik retikulumden salgılandıktan sonra golgi cisimciğinde glikolize olmakta, epitel hücrelerin apikal membranına yerleşip klor kanalı ve bikarbonat iyonlarının taşınımında mediatör görevi göstermektedir (31). cAMP ve protein kinaz A ile aktifleşen CFTR proteini epitel yüzeydeki sıvı homeostazisi ile birlikte diğer klor kanallarının ve epitel sodyum kanallarının regülasyonundan sorumludur (32). Na+ kanallarından biri olan ENaC ve Na/K ATPaz pompalarıyla birlikte $\mathrm{Na}+$ emilimini ve glutatyon gibi küçük moleküllerin geçişinin de düzenlenmesinde görev almaktadır (33).

Kistik fibrozis hastalarının hava yollarında iyon dengesinin bozulması ile birlikte mukus birikimi ve bakteri yerleşimine uygun bir ortam oluşmaktadır (34). Silyaların düzgün çalışamaması ve mukosiliyer klirensin bozulması, hava yolundaki inflamasyonu ve enfeksiyonları beraberinde getirmektedir. Mukosiliyer klirensin azalması ile birlikte IL-8 ve IL-6 ifadelerindeki artış, epitel hücrelerde etkilenen temel yolağın inflamasyon yanıtı olduğunu göstermektedir (35). Ayrıca CFTR ile ilişkili yolaklarda (iyon transferi, Nuclear factor kappa B subunit 1 (NFkB) ve Activator protein 1 (AP1) sinyal yolakları, IL-1及, bFGF IKKbağımlı IkB-a ve ERK aktivasyonu yolakları) görev alan genlerin (adezyon molekülleri, kemokinler, sitokin/büyüme faktörleri, sitokin reseptörleri, matriks yeniden modellemede görev alan genler) ifadesinde azalış saptanmıştır. IL-8 promotöründe AP-1 bağlanma bölgeleri tespit edilmiş olup; hastalık durumunda IL-8'de meydana gelen artıșın AP-1 aktivasyonuna yol açabileceği ve bu aktivasyonun kistik fibrozis patolojisinde rol oynayabileceği düşünülmektedir. Mutant CFTR ile NFkB ve AP-1 aktivasyonu arasındaki ilişki henüz aydınlatılmamış olsa da CFTR proteininin katlanması ve taşınması sırasında meydana gelen hatalar sonucu NFkB ve AP-1 yolaklarının aktive edildiği düşünülmektedir (36).

Farklı gruplar tarafından gerçekleştirilen transkriptom çalışmalarının sonucunda ortak olarak hastalarda immün cevabın sürekli uyarılması ile bitmeyen bir inflamasyon ve ona eşlik eden hastalıklar saptanmıștır. Ayrıca mukosiliyer klirens ve inflamatuar yolakların araştırıldığı çalışmalarda silyanın yapısı ve işlevinin de dolaylı olarak bozulduğu savunulmaktadır. Andrea J. Ross ve ark.' larının (37) hava yolu epitel biyolojisi ve farklılaşmasını araştırdıkları transkriptom çalışmasında hareketli silyogenezin en önemli düzenleyici transkripsiyon faktörlerinin FOXJ1 ve NOTO olduğu saptanmıştır. 326 potansiyel FOXJ1 bağımlı siliyer faktör tanımlanmış ve olgunlaşan akciğer epitelinde ifadelerinin arttığı, FOXJ1 yokluğunda ise siliyer faktörlerin ifadelerinin azaldığı bulunmuştur. FOXJ1 varlığında bronşiyal epitel hücrelerdeki mukosiliyer farklılaşmanın gerçekleştiği belirlenmiş olup; hücre farkılıașması sırasında transkripsiyonel olarak düzenlenen çeșitli sinyal yolakları ile gen ağları oluşturulmuştur. Ostrowski ve ark. (38) silyalı hücreye özgü bir FOXJ1 promotörü geliştirerek Enhanced green fluorescent protein (EGFP) işaretli transgenik fareler üretmiş ve EGFP oranına göre FOXJ1'ın trakeal, akciğer ve nazal dokuların epitel yüzeyine yerleştiğini ve protein miktarında 
artış görüldüğünü saptamışlardır. Aynı zamanda silya yapısının düzeldiğini ve silya sayısının arttığını göstermişlerdir. Bu nedenle kistik fibroziste FOXJ1'in tedavi hedefi olarak kullanılabileceği savunulmuștur. Clarke ve ark.'ları (39) ise F508del homozigot hastalardan elde edilen nazal epitel hücreleri ile gerçekleştirdikleri transkriptom çalışmasında; hastalarda hücre çoğalmasında görevli genlerin (ADM, AQP9, AREG, GJA1, IGFBP3, NDRG1 ve TMEM45A) ifadesinin arttığı ve silya oluşumunda görevli genlerin (SCGB1A1, SPAG6 ve TEKT1) ifadesinin azaldığı bulunmuştur. Ayrıca çalışma kapsamı genișletilip 13 farklı transkriptomik verinin bir arada analiz edildiği meta-analiz çalışmasında, mukus oluşumu ve klirensi ile ilişkili aksonemal genler olan DNAH9, DNAH12, DNA/1, DNAI2 ve DNAAF1 ifadesinin azaldığı, silyum veya sperm flagellum fonksiyonunda rol oynayan genlerin ifadesinin azaldığı saptanmıştır (40). DNAH9 ve DNAH12 dış dynein kolu yapısını, DNAl1 ve DNAl2 ise iç dynein kolu yapısını oluşturan proteinler olup; DNAAF1 siliyer yapının stabilitesi için gereklidir (41-43). Mutasyonlar sebebiyle bu genlerin ifadelerindeki azalma, silya yapısında ve işlevinde bozukluğa sebep olmaktadır. Mutasyonlara ek olarak mukosiliyer klirensin bozulması sonucunda CFTR işlevinin azalmasının hava yolundaki silya hareketini azalttığı ve böylece hastalık fenotipinin oluşabileceği düşünülmektedir.

\section{Primer Siliyer Diskinezi (PSD)}

Primer siliyer diskinezi (PSD), silyaların yapı ve fonksiyonunda doğum öncesinde olușan bazı bozukluklar ve anormalliklerden kaynaklanmaktadır. PSD genellikle otozomal resesif olarak kalıtımakla birlikte, X' e bağlı kalıımın nadir vakaları bildirilmiștir. PSD hastalarında embriyonik dönemde nodal silya hatalarından dolayı organ yerleșiminde situs-inversus gözlemlenmektedir. Mukosiliyer klirenste bozulma ve kısırlık sık görülenen klinik bulgulardır. PSD' den sorumlu yaklaşık 50 gen tanımlanmış olup; hastalık siliyer atım frekansının bozulması ve siliyer atım paternindeki değişiklikler ile karakterize olmaktadır (44). PSD sıklı̆ının 15000-16000 yeni doğanda 1 ortaya çıktı̆ı rapor edilmektedir ve bu sıklık akraba evliliğinin fazla olduğu Türk toplumu gibi toplumlarda daha yüksektir (45).

PSD, \%65'inde diş dynein kolunda ve/veya iç dynein kolunda meydana gelen mutasyonlar sonucu görülmektedir (46). ARMC4, C21orf59, CCDC103. CCDC114, CCDC151, NME8, MNS1, DNAH5, DNAH6, DNAH8, DNAH9, DNAH11, DNAI1, DNAI2, DNAL1 ve TTC25 diş dynein kolunun; CCDC39, CCDC40, DNAH1, DNAH7 ve DNAL11 iç dynein kolunun oluşumundan sorumlu genlerdir. Ayrıca iç dynein kolunda $R S P H 1, R S P H 3, R S P H 4 A$ ve $R S P H 9$ genleri tarafindan radyal bağlantı yapısı oluşmaktadır. İ̧ ve dış dynein kolu yapılarının ikisinde de ortak etkili olduğu düșünülen DNAAF1, DNAAF2, DNAAF3, DNAAF4, DNAAF5, LRRC6, SPAG1 ve ZMYND10 genlerindeki mutasyonlar sonucunda ise hastallk ciddiyetinde artış görülmektedir. Kistik fibroziste de ifadesi azalan genlerin yanında DNAH5 ve DNAl1 gibi genlerindeki mutasyonlar sonucu iç dynein kolunun bağlanma kompleksinde, protein taşınmasında hatalar meydana gelmektedir ve ATP bağımlı silya hareketi düzgün gerçekleșememektedir. Mikrotübüller üzerinde etkili olduğu bilinen EPB41L4A ve RPGR genleri silyaların aksonem yapısında hatalara neden olmakta ve silya hareketi bozulmaktadır. Hastaların bir kısmında da CCNO mutasyonu sebebiyle sentriyol oluşumunda hatalar meydana geldiği için silya sayısı azalmaktadır. CCNO'ya ek olarak silya sayısı azalmasına neden olan MCIDAS, OFD1, WDR5 ve TEKT1 genleri de bulunmaktadir. Bu genlerin FOXJ1 üzerindeki etkilerinden dolayı silyogenez, siliyer atım frekansı ve paternindeki değişikliklere sebep olduğu düșünülmektedir. Ayrica $D R C 1, D R C 2, D R C 4$ ve HYDIN genlerindeki mutasyonlar sonucunda neksin-dynein kompleksi bozulmakta ve silya hareketi düzgün gerçekleşememektedir $(47,48)$. Maiti ve ark. 'ları (49) tarafından PSD hastalarının nazal epitel hücrelerinde genom çapında bir tarama gerçekleștirilmiş ve FOXJ1 geninin PSD fenotiplerinden sorumlu olduğunu düşündüren hiçbir mutasyon bulunamamıştır. 2019 ylında Mukherjee ve ark.'ları (50) FOXJ1 aracılı sinyal ağlarıın hareketli silyalar interaktomunun en önemli belirleyicisi olduğunu göstermiş ve FOXJ1'in aracillk ettiği protein-protein etkileşim ağını biyoinformatik veri tabanları yardımı ile oluşturmuşlardır. Bu analizler sonucunda FOXJ1 induced genes (FIG) genleri tarafindan sentezlenen proteinlerle etkileșime giren ve silyalı hücrelerde ifade edilen yaklașık 120 protein tanımlanmıştır. Örneğin silyogeneze etki ettiği bilinen MCIDAS geni hareketli silyaların sayısının azalmasına neden olmakta ve mukosiliyer klirens mekanizmasına etki etmektedir. Bu nedenlerle MCIDAS silyalı hücre farklllaşması için CyclinO/ FOXJ1'in önemli bir düzenleyicisi olarak tanımlanmaktadır. Silyalar ile ilişkili sinyal yolaklarında ise (Notch, Wnt, Hedgehog, Toll- benzeri reseptör) yer alan proteinler aynı zamanda FOXJ1'ın etki ettiği olası siliyer biyoloji ve fonksiyon ile ilișkili olan ağ haritasında da yer almaktadır. Ayrıca FOXJ1'ın Hedgehog ve Wnt sinyal yolaklarında yer alması, PSD hastalarında görülen gelişim bozukluklarının FOXJ1 kaynaklı olabileceğini desteklemektedir.

\section{Kronik Obstrüktif Akciğer Hastalığı}

Kronik obstrüktif akciğer hastalığı (KOAH) bronșların ve hava yollarında uzun süreli tıkanma ile ortaya çıkmakta olup genellikle erişkin yaş grubunda görülse de sigara içen çocuklarda da görülebilmektedir. Solunum güçlüğü, öksürük ve nefes darlığı gibi şikayetlerle karakterize olan kronik bir hastalıktır. Klinik ciddiyete göre hafif, orta, ağır ve çok ağır olacak şekilde 4 gruba ayrılmaktadır (51).

Tasena ve ark.'ları (52) KOAH hastalarında görülen hiper sekresyonun altında yatan moleküler mekanizmaları araştırmak üzere, hastalardan elde ettikleri bronşiyal biyopsileri kullanarak 20 adet mikroRNA (miRNA) ve miRNA hedefleri olan 539 
adet mRNA tanımlayarak, miRNA-mRNA etkileşim ağlarını oluşturmuşlardır (Tablo I). Analizler sonucunda mukosiliyer klirense etki ettiği bilinen ve mukusun jel yapısını oluşturan MUC5AC ve MUC5B ifadesinin KOAH hastalarında arttığı belirlenmiștir (52). Hiper sekresyon sonucunda epitel yüzeyde görülen tıkanıklık sonucunda mukus klirensi bozulmaktadır. Epitel hücre üzerindeki silyalar, silya fonksiyonunun önemli bir ölçüsü olan siliyer atım frekansı ile mukosiliyer klirense katkıda bulunmaktadır (53). 2012 yılında Yaghi ve ark.'ları (54) silya atım frekansının $\mathrm{KOAH}$ şiddeti ile ilişkisini orta ve ağır seyirli hastalarda nazal silya atım frekansının azaldığını saptamışlardır. Aynı zamanda siliyer fonksiyon bozukluğunun KOAH'ta mukosiliyer klirensi etkileyebileceğini ve enfeksiyonlara yol açabileceğini göstermişlerdir. İstatistiksel olarak anlamlı görülmemesine rağmen orta ve ağır seyirli $\mathrm{KOAH}$ hastalarında silya atım frekansı önemli ölçüde baskılanmıştır. Kontrol bireylere kıyasla, KOAH hastalarının nazal silya atım frekansının çeşitli farmakolojik ajanlarla (YM976 ve tiotropium bromür) arttırılabildiği gösterilmiş olup; silyalar yardımıyla hava yolundaki yabancı maddelerin temizlenmesinde bir artış gözlemlenmiştir. Ayrıca KOAH hastalarında sigaranın epigenetik etkilerle ortaya çıkardığı değişikliklerin, silyalarda çeşitli bozukluklara yol açtığı bilinmektedir. Gohy ve ark.'larının (53) 2019 yılında yaptığı bir çalışmaya göre KOAH'lı akciğer örneklerinde, kontrollere kıyasla MUC5AC ifadesi artmış, a-tubulin ve FOXJ1 ifadesi azalmıştır. Aktif sigara içen hastalarda, sigara içmeyenlere göre daha yüksek MUC5AC ifadesi saptanmış ve bu ifade değişimi sigara kullanımına bağlanmıștır. Sonuç olarak silyalı hücrelerin oluşumundaki hatalar, siliyer uzunluğun ve atım frekansının azalmasına neden olmakta ve bu durumun KOAH'ta bozulmuş mukosiliyer klirens ile sonuçlanabileceği düşünülmektedir. Mekanik yöntemlere ek olarak silya atım frekansı ve mukosiliyer klirens mekanizması ile ilişkili yolakların moleküler düzeyde daha fazla araştırıması gerekmektedir.

\section{SONUÇ}

Memelilerde transkripsiyon faktörü olan FOXJ1, hareketli silya oluşumunda rol oynamaktadır. Yapılan çalışmalarda FOXJ1 aktivitesinden yoksun farelerin, hareketli silya sayısında azalma veya kayıp saptanmış olup; FOXJ1 geninin hareketli silya oluşumunda temel bir role sahip olduğu gösterilmiştir. Solunum yolu hastalıkları arasında hareketli silya yapı bozuklukları ve mukosiliyer klirens mekanizması ortak olarak belirlenmiştir. PSD, $K F$ ve KOAH'da FOXJ1 geninin doğrudan ya da dolaylı olarak ifadesinin değișimi ile akciğer patofizyolojisi etkilenmektedir. Aynı zamanda FOXJ1 ifadesinin artışı silya yapısını, sayısını ve silya atım frekansını da düzeltmektedir (55).

Grubumuz tarafından kistik fibrozis hastalarında fenotipik ciddiyeti etkileyen genlerin araştıııması amacıyla gerçekleştirilen hedefli transkriptomik çalışmasında hasta ve kontrol bireylerin transkript seviyeleri karşılaştırılmıştır (56). Silya yapı ve işlevi bakımından değerlendirdiğimiz ön çalışma sonuçlarımıza göre mukosiliyer klirense etki edebilecek FAS (kat değişimi: 3.68), ICAM1 (kat değişimi: 4.29), IL6 (kat değişimi: 9.6), IL10 (kat değişimi: 4.67), TLR2 (kat değişimi: 2.05), TLR4 (kat değişimi: 2.88), TNF (kat değişimi: 5.5), CCl2 (kat değişimi: 9.01), CXCL2 (kat değişimi: 3.97) ve CXCL1 (kat değişimi: 2.8) genlerinin ifadelerinde kontrol grubuna göre artıș saptanmıștır. CXCL8 (kat değişimi: 2.08) ifadesinde ise azalış görülmüştür. Yolak analizleri sonucunda TNF, IL-17, NF-kappa B, NLRP3 inflamazom ve sitokin-sitokin reseptör sinyal yolaklarının etkilendiği gösterilmiştir. Hastalarda kontrol bireylere göre artış gösteren TNF ve TNF reseptörlerinin bulunduğu sinyal yolağının aktifleşmesi sonucu NF kappa B aracılı proinflamatuar sitokinlerin salınımı gerçekleşmektedir. Proinflamatuar sitokinlerin salınımı, nekroptozis yolağının aktifleşmesinde görevli nekroptozom komplekslerinin oluşmasını tetikleyerek hücrede NLRP3 inflamazom yolağını harekete geçirdiği düşünülmektedir.

Sonuç olarak; PSD, KF ve KOAH gibi solunum yolu hastalıklarında hareketli silya yapı ve işlev bozukluklarının araştırılması; sonuçların mukosiliyer klirens ve inflamasyon açılarından değerlendirilmesi ile hastalıkların moleküler temellerinin aydınlatılması ve yeni tedavi hedeflerinin saptanması mümkün olabilecektir.

\section{KAYNAKLAR}

1. Beales P, Jackson P. Cilia - the prodigal organelle. Cilia 2012;1:1.

2. Tsang K, Tipoe G, Mak J, Sun J, Wong M, Leung R, et al. Ciliary central microtubular orientation is of no clinical significance in bronchiectasis. Respir Med 2005;99:290-7.

3. Ishikawa H, Marshall W. Ciliogenesis: building the cell's antenna. Nat Rev Mol Cell Biol 2011;12:222-34.

4. Bustamante-Marin X, Ostrowski L. Cilia and Mucociliary Clearance. Cold Spring Harb Perspect Biol 2017;9:a028241.

5. Choksi S, Lauter G, Swoboda P, Roy S. Switching on cilia: transcriptional networks regulating ciliogenesis. Development 2014;141:1427-41.

6. Brown J, Witman G. Cilia and Diseases. Bioscience 2014;64:112637.

7. Tilley A, Walters M, Shaykhiev R, Crystal R. Cilia Dysfunction in Lung Disease. Annu Rev Physiol 2015;77:379-406.

8. Goodenough U, Heuser J. Outer and inner dynein arms of cilia and flagella. Cell 1985;41:341-2.

9. Gueron S, Liron N. Ciliary motion modeling, and dynamic multicilia interactions. Biophys J 1992;63:1045-58.

10. Pazour G, Rosenbaum J. Intraflagellar transport and ciliadependent diseases. Trends Cell Biol 2002;12:551-5.

11. Martin-Hurtado A, Lastres-Becker I, Cuadrado A, Garcia-Gonzalo F. NRF2 and Primary Cilia: An Emerging Partnership. Antioxidants (Basel) 2020;9:475.

12. Rosenbaum J. Intraflagellar transport. Nat Rev Mol Cell Biol 2002;3: 813-25.

13. Whitsett J. Airway Epithelial Differentiation and Mucociliary Clearance. Ann Am Thorac Soc 2018;15(Suppl3):S143-8. 
14. Tadokoro T, Wang Y, Barak L, Bai Y, Randell S, Hogan B. IL-6/ STAT3 promotes regeneration of airway ciliated cells from basal stem cells. Proc Natl Acad Sci U S A 2014;111: E3641-9.

15. Turner J, Roger J, Fitau J, Combe D, Giddings J, Heeke G, et al. Goblet Cells Are Derived from aFOXJ1-Expressing Progenitor in a Human Airway Epithelium. Am J Respir Cell Mol Biol 2011;44:27684.

16. Look D, Walter M, Williamson M, Pang L, You Y, Sreshta J, et al. Effects of Paramyxoviral Infection on Airway Epithelial Cell FOXJ1 Expression, Ciliogenesis, and Mucociliary Function. Am J Pathol 2001;159:2055-69.

17. Wanner A, Salathé M, O’Riordan T. Mucociliary clearance in the airways. Am J Respir Crit Care Med 1996;154:1868-902.

18. Houtmeyers E, Gosselink R, Gayan-Ramirez G, Decramer M. Regulation of mucociliary clearance in health and disease. Eur Respir J 1999;13:1177-88.

19. Rubin B. Mucus and Mucins. Otolaryngol Clin North Am 2010;43:27-34.

20. Bonser L, Erle D. Airway Mucus and Asthma: The Role of MUC5AC and MUC5B. J Clin Med 2017;6:112.

21. Thai P, Loukoianov A, Wachi S, Wu R. Regulation of Airway Mucin Gene Expression. Annu Rev Physiol 2008;70:405-29.

22. Chilvers M, O'Callaghan C. Local mucociliary defence mechanisms. Paediatr Respir Rev 2000;1:27-34.

23. Cantin L, Bankier A, Eisenberg R. Bronchiectasis. AJR Am J Roentgenol 2009;193:W158-W171.

24. Lewis B, Patial S, Saini Y. Immunopathology of Airway Surface Liquid Dehydration Disease. J Immunol Res 2019;2019:2180409.

25. Courtney J, Ennis M, Elborn J. Cytokines and inflammatory mediators in cystic fibrosis. J Cyst Fibros 2004;3:223-31.

26. Guan W, Peng Y, Zi X, Tan K, He T, Zhong N, et al. Motile Ciliary Disorders in Chronic Airway Inflammatory Diseases: Critical Target for Interventions. Curr Allergy Asthma Rep 2018;18:48.

27. Mukherjee I, Roy S, Chakrabarti S. Identification of Important Effector Proteins in the FOXJ1 Transcriptional Network Associated With Ciliogenesis and Ciliary Function. Front Genet 2019;10:23.

28. Rafeeq M, Murad H. Cystic fibrosis: current therapeutic targets and future approaches. J Transl Med 2017;15:84.

29. Clinical and Functional translation of CFTR. Erişim tarihi: 12 Mart 2021. Available from: https://www.CFTR2.org.

30. Cystic Fibrosis Mutation Database. Erişim tarihi: 12 Mart 2021. Available from: http://www.genet.sickkids.on.ca/

31. Richards C, Bradley L, Amos J, Allitto B, Grody W, Maddalena A, et al. Standards and Guidelines for CFTR Mutation Testing. Genet Med 2002;4:379-91.

32. Dayangaç-Erden D, Atalay M, Emiralioğlu N, Hızal M, Polat S, Özçelik U, et al. Mutations of the CFTR gene and novel variants in Turkish patients with cystic fibrosis: 24-years experience. Clin Chim Acta 2020;510:252-9.

33. Cutting G. Cystic fibrosis genetics: from molecular understanding to clinical application. Nat Rev Genet 2015;16:45-56.

34. Ratjen F, Bell S, Rowe S, Goss C, Quittner A, Bush A. Cystic fibrosis. Nat Rev Dis Primers 2015;1:15010.

35. Tsui L, Dorfman R. The Cystic Fibrosis Gene: A Molecular Genetic Perspective. Cold Spring Harb Perspect Med 2013;3:a009472.

36. Steinkamp G, Wiedemann B, Rietschel E, Krahl A, Gielen J, Barmeier $\mathrm{H}$, et al. Prospective evaluation of emerging bacteria in cystic fibrosis. J Cyst Fibros 2005;4:41-8.
37. McShane D, Davies J, Wodehouse T, Bush A, Geddes D, Alton E. Normal nasal mucociliary clearance in CF children: evidence against a CFTR-related defect. Eur Respir J 2004;24:95-100.

38. Verhaeghe C, Remouchamps C, Hennuy B, Vanderplasschen A, Chariot A, Tabruyn S, et al. Role of IKK and ERK pathways in intrinsic inflammation of cystic fibrosis airways. Biochem Pharmacol 2007;73:1982-94.

39. Ross A, Dailey L, Brighton L, Devlin R. Transcriptional Profiling of Mucociliary Differentiation in Human Airway Epithelial Cells. Am J Respir Cell Mol Biol 2007;37:169-85.

40. Ostrowski L, Yin W, Diggs P, Rogers T, O’Neal W, Grubb B. Expression of CFTR from a ciliated cell-specific promoter is ineffective at correcting nasal potential difference in CF mice. Gene Ther 2007;14:1492-501.

41. Clarke L, Sousa L, Amaral M. WS20.3 Changes in transcriptomics of native nasal epithelium expressing F508del-CFTR and intersecting data from comparable studies. J Cyst Fibros 2013;14:38.

42. Clarke L, Botelho H, Sousa L, Falcao A, Amaral M. Transcriptome meta-analysis reveals common differential and global gene expression profiles in cystic fibrosis and other respiratory disorders and identifies CFTR regulators. Genomics 2015;106:268-77.

43. Maiti A, Mattéi $M$, Jorissen $M$, Volz A, Zeigler A, Bouvagnet P. Identification, tissue specific expression, and chromosomal localisation of several human dynein heavy chain genes. Eur J Hum Genet 2000;8:923-32.

44. Loges N, Olbrich H, Fenske L, Mussaffi H, Horvath J, Fliegauf M, et al. DNAl2 Mutations Cause Primary Ciliary Dyskinesia with Defects in the Outer Dynein Arm. Am J Hum Genet 2008;83:547-58.

45. Horani A, Ferkol T. Advances in the Genetics of Primary Ciliary Dyskinesia. Chest 2018;154:645-52.

46. Baz-Redón N, Rovira-Amigo S, Camats-Tarruella N, Fernández-Cancio $M$, Garrido-Pontnou $M$, Antolín $M$, et al. Role of Immunofluorescence and Molecular Diagnosis in the Characterization of Primary Ciliary Dyskinesia. Arch Bronconeumol 2019;55:439-41.

47. Meeks M, Bush A. Primary ciliary dyskinesia (PCD). Pediatr Pulmonol 2000;29:307-16.

48. Emiralioğlu N, Taşkıran E, Koşukcu C, Bilgiç E, Atilla P, Kaya B, et al. Genotype and phenotype evaluation of patients with primary ciliary dyskinesia: First results from Turkey. Pediatr Pulmonol 2020;55:383-93.

49. Baz-Redón N, Rovira-Amigo S, Paramonov I, Castillo-Corullón S, Roig M, Antolín M, et al. Implementation of a gene panel for genetic diagnosis of primary ciliary dyskinesia. Arch Bronconeumol 2020;S0300-2896:30073-9.

50. Milla C. The evolving spectrum of ciliopathies and respiratory disease. Curr Opin Pediatr 2016;28:339-47.

51. Maiti A, Bartoloni L, Mitchison H, Meeks M, Chung E, Spiden S, et al. No deleterious mutations in the FOXJ1 (alias HFH-4) gene in patients with Primary Ciliary Dyskinesia (PCD). Cytogenet Genome Res 2000;90:119-22.

52. Han M, Agusti A, Calverley P, Celli B, Criner G, Curtis J, et al. Chronic obstructive pulmonary disease phenotypes: the future of COPD. Am J Respir Crit Care Med 2010;182:598-604.

53. Tasena H, Faiz A, Timens W, Noordhoek J, Hylkema M, Gosens $\mathrm{R}$, et al. microRNA-mRNA regulatory networks underlying chronic mucus hypersecretion in COPD. Eur Respir J 2018;52:1701556.

54. Gohy S, Carlier F, Fregimilicka C, Detry B, Lecocq M, Ladjemi $\mathrm{M}$, et al. Altered generation of ciliated cells in chronic obstructive pulmonary disease. Sci Rep 2019;9:17963. 
55. Yaghi A, Zaman A, Cox G, Dolovich M. Ciliary beating is depressed in nasal cilia from chronic obstructive pulmonary disease subjects. Respir Med 2012;106:1139-47.

56. McShane D, Davies JC, Wodehouse T, Bush A, Geddes D, Alton W. Normal nasal mucociliary clearance in CF children: evidence against a CFTR-related defect. Eur Respir J 2004;24:95-100.

57. Verhaeghe C, Delbecque K, de Leval L, Oury C, Bours V. Early inflammation in the airways of a cystic fibrosis foetus. J Cyst Fibros 2007; 6:304-8.

58. Davis SD, Rosenfeld M, Lee HS, Ferkol TW, Sagel SD, Dell SD et al. Primary ciliary dyskinesia: longitudinal study of lung disease by ultrastructure defect and genotype. Am J Respir Crit Care Med 2019;199:190-8.
59. Baz-Redón N, Rovira-Amigo S, Camats-Tarruella N, Fernández-Cancio M, Garrido-Pontnou M, Antolín $M$, et al. Role of Immunofluorescence and Molecular Diagnosis in the Characterization of Primary Ciliary Dyskinesia. Arch Bronconeumol (Engl Ed) 2019; 55:439-41.

60. Yu X, Ng C, Habacher H, Roy S. FOXJ1 transcription factors are master regulators of the motile ciliogenic program. Nat Genet 2008;40:1445-53.

61. Ekinci İ, Hızal M, Emiralioğlu N, Özçelik U, Yalçın E, Doğru D, et al. Differentially expressed genes associated with disease severity in siblings with cystic fibrosis. Pediatr Pulmonol 2021; 56:910-20. 